\title{
Exploring Evolution and Survival of Large age-gap Romantic Heterosexual Relationships involving Older Women and Younger Men in Chipata, Zambia
}

\author{
Jordan Tembo ${ }^{1}$, Patricia Mambwe ${ }^{2}$ \\ ${ }^{1}$ Kalindawalo General Hospital, 560008, Petauke, Eastern Province, Zambia \\ ${ }^{2}$ Department of Nursing, School of Health Sciences, Rusangu University, Monze, Zambia
}

\begin{abstract}
Older woman/ younger man romantic relationships are also referred to as 'May- December' relationships because one partner is younger/ the younger man while the other partner is older/the older woman. These relationships are now a social reality in both rural and urban societies. No wonder, scholarly interest has been increasingly gaining ground around the subject for the purpose of understanding this social phenomenon. However, evolution and survival of these relationships remain unclear in academic circles. The objective of this study was to find out how large age gap romantic heterosexual relationships involving an older woman and a younger man develop and survive under harsh societal opposition. Using a cross-sectional design with a qualitative approach, the study was conducted in Chipata-Zambia between December 2020 and March, 2021. A total of 10 participants stratified as: 2 younger men married to older women, 4 younger men with a history of intimate relationship with older women, 2 females with relatives/neighbour who were hooked up with older women and 2 males whose younger male friends were cohabiting with aged women. The study used in-depth interview to collect data from participants. This study found that majority of these relationships developed coincidentally. Except in one case, the study found that older women did not pose as 'assertive seductresses' ready to defy social norms in order to date younger men. The study however, found that older women's invitational or male-ego-challenging words, actions and non verbal language influenced the course leading to the formation of romantic relationships with son-like figures. The study also found that agedescripant couples stuck together despite harsh stereotypes when their relationship was characterized by respect, love and appreciation for each other.
\end{abstract}

Key words: Age-gap, romantic, heterosexual, descripant

\section{BACKGROUND}

$\mathrm{W}$ orlds apart- is a fitting statement describing the two social worlds occupied by an older female and a younger man. To begin with, their world views are different, pursuits and priorities different, frontier interests different, life lessons accumulated different: one has seen, heard, and tasted it all while the other an excited novice pounding everywhere for social identity, social recognition and a social place in society. In addition to these stark contrasts, social norms stretch the differences even further by ring-fencing each of these categories into two polar social camps. The camps are culturally exclusive. There is no common ground. In nearly all societies, the cultural code forbids a younger man to prod the prohibited older woman-social-zone for romance.

But the traditional well known relationship structure of yester years 'between men and women has significantly changed. Underlying this change is a new trend of older women getting involved in a romantic relationship with younger men' (Fan, 2016:892). Di Fan(2016) adds, 'in the media movement this kind of relationship is popularly referred to as 'MaySeptember' or 'May- December' romances' implying large age gap between partners (Fan 2016: 892). Scholars observe that diminishing male dominance as the female becomes more independent is largely the cause. Proulx, Caron and Logue (2006) chime this observation through a poignant declaration that as women get 'socially and economically independent they become less likely to conform to traditional patterns characterized by older male-younger female relationships' (Proulx et al., 2006: 45). Most importantly, 'finding a suitable partner is challenging for older women' (Ajrouch, Blandon \& Antonucci, 2005 in McWilliams \& Barrett, 2017). To find love or feel loved again, older women are tempted to hew the cultural hedge or use their discretionary rights and step out into socially restricted grasslands. They rebel against submitting to the cultural expectation of older man-younger woman to access the only available option in their narrowed 'love market'.

Scholarly interest has been focused 'mainly only relationships between older males and younger females than on older females and younger men or boys' (Masenya 2017:120). Studies on age-descripant relationships involving older women and younger men have been restricted to the implication of older Women/Younger men intimancy ((Proulx et al., 2006); why older women do not prefer much older men (Spinelli, Hantori and Cordeiro de Sousa, 2010), and older women's accounts of sexual interplay in large age gap intimate relationships (Alarie, 2019). Lack of sufficient scholarly interest in the area has left out the mechanics of how such relationships develop and survive. There is little understanding over the facets surrounding the evolution of older woman/younger man intimate relationships. It is unclear how such relationships develop and receive sustenance. Important questions designed to navigate the contours of such relationships remain unanswered. Critical of these questions 
are who initiates such relationships? How do the players sustain such relationships under societal scrutiny and brutal opposition especially in conservative societies? This study set out to answer these questions. The study was conducted in Chipata, Zambia. Chipata was formerly called Fort Jameson. The 'Fort' comes from fortress. Chipata's encircling mountain range created a fortress to the colonial settlers against local and foreign invasion. Chipata is now the Provincial Head quarters of Eastern Province, Zambia. It was declared a city in 2017. Following the sequestration and creation of two more new districts out of Chipata, the city's population trimmed to 288,000 people as at December 2019. Originally, the city is home to the Ngoni speaking people whose ancestors fled Shaka Zulu's wars in South Africa during the $19^{\text {th }}$ Century. In recent years, Chipata has witnessed explosive migration of locals, other tribes and nationals into the city.

The super grade A tarred road that connects Chipata and the neighbouring Malawi adds beauty and traffic to the city but above all it makes it easier for those carrying cargo to navigate the city smoothly. Booming with economic activities such as farming, trade, construction, transport, the once sleepy town is now socially alive.

\section{MATERIALS AND METHODS}

Explorative studies focused on understanding the dynamics of large age-gap heterosexual romantic relationships involving older females and younger men are not available in Zambia. This study used a cross-sectional design with a qualitative descriptive approach to harvest rich informative data. The study was conducted between December 2020 to March, 2021. The study used the single-interview-per-participant data collection method. Participants for the study were drawn from younger men married to older women, 'toy boys' with history of an intimate relationship with an older woman and those who witnessed a friend or relative hook up with an older woman. Commenting on adequate sample size for a qualitative study, Shari Dworkin (2019), in the article titled Sample Size Policy for qualitative Studies Using In-depth Interviews, observed that 'an extremely large number of articles, books chapters, and books recommend guidance and suggest anywhere from 5 to 50 participants as adequate' (Dworkin 2012: 1319). This study used 10 participants layered into : 2 younger men married to older women, 4 younger men with a history of intimate relationship with an older woman, 2 females with relatives who had hooked up with older women and 2 males whose younger male friends were cohabiting with aged women. The wider participant category involvement was meant to "obtain the broadest range of information and perspectives on the subject of study" (Kuzel 1992:37). Due to the sensitive nature of the subject under study, researchers understood that it would be difficult to find suitable participants and if found, any careless approach had potential to scare them away. Researchers were therefore, careful, first to build rapport and gain trust with the locals. It is out of the rapport, that 4 younger men came out and reported that they had been involved intimately with elderly women. These potential participants were helpful again in connecting the researchers to the younger men who were cohabiting with elderly women. Additional 4 participants- 2 younger women and 2 younger men also reported that that either they had a relative, a friend or a neighbour who was involved in an age-discrepant heterosexual romance.

Anonymity and confidentiality were assured as participants' names were not to be recorded anywhere neither were participants allowed to introduce themselves using their names. Interviews were conducted at different points away from the city's hustle and bustle to ensure privacy and confidentiality. Interviews were conducted in an atmosphere of informality so that participants could feel free to share their perspective. Each interview lasted 60minutes. Refreshments were provided at the end of the interview for hydration only. After data collection, recorded interviews were listened to several times. This was done to ensure interviewees' perspectives were familiar for theme emergence.

\section{Social Theory}

This study was guided by the Social Exchange Theory. Social Exchange Theory is based on the orientation that people weigh costs and rewards in a relationship setting (Redmond 2015).Susan Sprecher (2010) argues that Social Exchange theory is relevant for understanding sexuality as it is negotiated between two people who have a relationship with each other (Sprecher 2010:32). Older women choose to form romantic relationships with younger men as they gain something in exchange, for if a relationship with a younger man does not provide her with a reward then she 'would not do it' (Sprecher 2010:32).

\section{RESULTS}

Table 1. Demographic characteristics of participants

\begin{tabular}{|c|c|}
\hline Gender & \\
\hline Males, $\mathrm{n}(\%)$ & $8(80 \%)$ \\
\hline Females, $\mathrm{n}(\%)$ & $2(20 \%)$ \\
\hline $\begin{array}{c}\text { Mean age in years for all } \\
\text { participants }\end{array}$ & 28 \\
\hline Education levels & 0 \\
\hline Primary not completed, $\mathrm{n}(\%)$ & 0 \\
\hline Primary completed, $\mathrm{n}(\%)$ & $6(60 \%)$ \\
\hline $\begin{array}{c}\text { Junior secondary not completed, } \\
\mathrm{n}(\%)\end{array}$ & 0 \\
\hline Junior Secondary completed, $\mathrm{n}(\%)$ & $1(10 \%)$ \\
\hline $\begin{array}{c}\text { Senior Secondary not completed, } \\
\mathrm{n}(\%)\end{array}$ & $3(30 \%)$ \\
\hline Senior Secondary completed, $\mathrm{n}(\%)$ & $1(10 \%)$ \\
\hline Marital Status & $2(20 \%)$ \\
\hline Married, $\mathrm{n}(\%)$ & $7(70 \%)$ \\
\hline Cohabiting $\mathrm{n}(\%)$ & \\
\hline Single, $\mathrm{n}(\%)$ & \\
\hline
\end{tabular}


Question. Who initiates an older woman/younger man romantic relationship?

The purpose of this question was meant to gain an understanding of who took the first step in the evolution of an age-discrepant relationship in which an older woman and a son-like figure engaged in romance. Knowing too well that each of the two players existed in a society where culture entirely forbade even the mention of such relationships. Who then between the two was more daring to step out of the social boundaries, rip social norms and reverse the social order? It was interesting to note that participants' answers were similar despite being interviewed on different days, weeks, months and locations. All the participants (100\%) pointed their finger at an older woman as the initiator of this kind of a relationship though the younger man's venturous mind was not ruled out. Two major themes that emerged from participants' responses on formation of cougar/ boy romantic relationship were older women's preference for a debt-servicing alternative other than money for goods or services.

\section{Debt servicing alternative for goods or services}

Participants reported that some older women initiated an intimate relationship with younger men following a grab of goods or services and when approached for payment, they implicitly or explicitly suggested romance as the available alternative to service their debt. The following two case studies highlight direct and indirect suggestions made by older women implying a call for romance with younger men.

\section{Case study of- Younger man Chakumanda}

The study begins with Chakumanda (not his real name) a grade nine dropout. At the time of interview in December, 2020, Chakumanda was 21 years old. He had been involved in an older woman/younger man relationship for one year in 2018. The older woman was nearly twice his age- 39years. The older woman and Chakumanda lived within the same neighbourhood in one of the slums in Chipata. They had known each other for years. The woman was single, had never been married before but had 6 children from different fathers. Two of her children were older than Chakumanda. After Chakumanda failed grade nine examinations in 2014, he turned his energy and attention towards making a living. 'I knew the only way I could find a better living after failing grade nine examinations was to engage in serious gardening.' He made full use of the traditional inherited land of his fathers. 'I grew cabbage, rape, onions, tomatoes, bananas including egg plants and carrots. My garden is still one of the success stories in our neighbourhood'. He sold his products in the neighbourhood as well as at the famous vegetable market in Chipata known as Saturday Market. 'I grew from strength to strength. I bought water pumps and employed workers. My role was supervision.' At that time he did not have intentions to find a woman for marriage let alone romance. 'Marrying or finding a girlfriend was not a priority. What preoccupied my mind was building a house for myself first and for my mother.' Chakumanda recollected what happened for him to meet the older woman. "What I remember is that I had brought a variety of garden parcels for sale in the neighbourhood. This older woman comes, gets sizeable quantities of heads of cabbage, tomatoes, onions and bananas.

She promised to pay me the following day.' Chakumanda did not object as the woman could sometimes get his goods on credit and faithfully pay back. When he followed up the older woman's promise he was told to come the next day. 'When I showed up at her house the next day she told me to come in the evening. Innocently I went thinking she would live up to her word.' Upon his arrival, the older woman welcomed him into her house and saved him food. 'She served me foodpotatoes, tea with milk, nshima and beef. Her food tasted differently as if it was hotel food. I ate freely.' After he was done with the feast, the woman came and knelt before him. 'She came knelt before me and asked whether I had enjoyed the meal to which I replied that I did. I thanked her profusely. She smiled and looked away shylily.' Chakumanda waited to see her go to her bedroom and bring his money but was surprised at what she told him. 'I was confused at first when she told me she did not have the money but was willing to clear the credit using alternative means'. When he asked what she meant by alternative means, 'she exposed her thigh. It was my first time to see what I saw. My heart beat wildly. My breathing changed. She held my hand and led me to her bedroom that's how I had my first encounter with a woman. For one year I failed to stop.' Even after the relationship ended Chakumanda lamented that the older woman introduced him to a strange world of love, 'from the time I fell in love with her it's like she cast a spell on me because I always fall in love with older women.'

\section{Case study of- Younger man Kezala}

Kezala (a pseudo name) was 32 years old. He is a taxi driver. He pirates within and outside Chipata. One day in 2017, one of the passengers he had picked was an older woman aged 48 years. The woman was a widow. She lived alone with a grandchild aged 8years. The woman was a regular customer. Kezala knew her house as he would drop her at the door step. When she dropped her at her home that day, she pretended to dig around in her handbag so she could cash him but found no money in the hand bag. She excused herself and went into the house to emerge a few minutes later without finding the money. 'Finally she just told me see I have looked for money everywhere and I can't find it. Perhaps you can come back later this evening.' Kezala returned that evening hoping to get his money. 'When I came back, the older woman told me mucite nane ciliconse kabili newo ndiye nili nankhongole namweo 'do whatever you want with me because I owe you'. Since she was his regular customer Kezala felt that it would be unfair to insist on her paying him his money. 'I could not write off her credit. So I decided to go along with what she was leading me to. So I slept with her'. However, the following day, he noticed something unusual. 'I experienced terrible discomfort on attempting to urinate. I knew the older woman had infected me with a Sexually Transmitted 
Infection. I went to the hospital. They got the pus-like discharge and examined it. They told me it was Gonorrhoea. They treated my condition. I have not gone back to the old woman. She is very dangerous. She can kill me.'

Question: How do heterosexual large age gap relationships between older women and younger men develop?

The purpose of this question was to reap informative data surrounding evolution of older woman/ younger man relationship. Two participants cohabiting with older women shared useful information. From participants' responses, two themes were constructed namely defense reaction to masculinity and lack of emotional intimancy.

\section{Defense Reaction to Masculinity}

One participant's oral narrative demonstrated how younger men, out of fear to be labelled impotent when faced with a challenge from a female, dived into an older woman/younger man relationship. The case study below illustrates how younger men sometimes react in defense of their sociocultural identity as men.

\section{Case study of- Younger man Pensulo}

The study begins with Pensulo (Pseudo name). Pensulo was 36 years old in January 2021. At the time of interview, Pensulo was cohabiting with an older woman aged 46 years. Facts were that Pensulo, a charcoal banner, while going round selling his charcoal he met the woman he was cohabiting with. 'Innocently I was going round the compound selling charcoal. From behind I heard a feminine voice calling; ba malasha! ba malasha! 'charcoal seller! Charcoal seller!' I stopped, waited for her.' The older woman requested for two bags of charcoal and promised to pay him in two days time. 'When I followed her for my money she challenged me in front of other women. She asked me what kind of a man I was who followed a woman over money.' He was told it was a man who should give the woman money and not the other way round. 'She told me a woman may not have money but she always has something to give a man'. Pensulo felt ashamed of himself especially after other women giggled. 'I felt ashamed, challenged and bare. You know in our culture it is so insulting and so demeaning to be tagged ngomwa - impotent.' Pensulo prepared himself for the last fight. 'I told myself I was a man. As a man I could not stand such cultural stereotypical words from a woman. So I went to her to prove myself that I was a man and that a real man conquers a woman in bed .' He spent a night at the older woman's house but when it was morning she refused to let him leave. 'When I told her I wanted to go she told me no one who spends a night with me leaves my home.' Pensulo was further intrigued. 'Proving her point, I saw her get my clothes and soak them in a bucket of water. This is how I was constrained to stay at her home to date.'

\section{Lack of emotional intimancy}

Response from one of the participant indicated that lonely older women lacking emotional intimacy were likely to slide into an environment where they choose to form an intimate relationship with younger men in search of love, companionship and emotional wellbeing. The case study below depicts the findings of the study.

\section{Case study of-Younger man Inki}

The study proceeds with Inki (pseudo name), a young man aged 28 years. Inki is a high school graduate. In 2019 on a weekend, in his pursuit for economic independence, he went door to door in search of a job as a garden boy in a residential area for the affluent. At one of the rich-looking houses, an older woman of about 40 years opened the gate and greeted him. Quickly, he introduced himself and submitted that he was looking for a job as a garden boy. To his surprise, the woman accepted and told him to report the following day. After working for 2 weeks, Inki noticed behavioural change from the woman. 'I noticed that she could leave the lights of the car on while she carried on with her business. She looked miserable. Each morning, she would tell me to eat her food she left the night before. Out of genuine concern for her, I gathered courage and asked her whether she was unwell and needed help.' Upon inquiry, Inki was invited in the house.

'She told me to come inside the house.' The older woman responded 'since you sound so caring, then I will tell you everything may be you can assist me.' Inki listened carefully as the older woman poured her heart intimating how lonely and unhappy she was in her life despite the money she had, a well-paying job, and a mansion. 'She told me that she was a very lonely and miserable woman in spite of the money, job, businesses, education and cars she possessed. I could not believe what she was telling me. She confused me even further when she sobbed uncontrollably. She narrated that her husband had abandoned her for another woman forcing her to feel so lonely, so unloved and unappreciated'. Inki's heart was touched. 'I hated her husband for being uncaring and unappreciative of a woman so kind. When she begged me to let her sob from my lap I was more than willing to offer any form of comfort.' Inki patted her back lightly as a measure of comfort. 'When I did that she pulled my hand and inserted it in her bra and signalled that I fondle her breasts. Inki thought educated women had a special way of getting comforted. 'At first I thought that was how educated women could be comforted.' But he was surprised to find that what began as a comforting exercise progressed to intimancy. 'That was the beginning of our romantic relationship and from then on, the older woman looked happier, socially active and involved. She told me she was lonely and bored and needed to feel loved'.

Question: How do large age gap heterosexual relationships sustain themselves under societal scrutiny and brutal opposition?

This question was designed to elicit information on how an older woman and her younger man intimate partner sustain their age-gap relationship despite an abhorrent, eye-rolling and palpable stigma from society for departing from social 
norms. Mature love, compatibility of behaviour and economic gain.

\section{Mature Love}

Participants' responses signalled that when older woman/younger man relationship develops, sometimes younger men are constrained to stay on in the relationship because of the unassuming mature love they experience from their partners. They experience motherly care, constructive advice which enables them to view life with grown-up lens. The case study below provides the scenario.

\section{Case study of- younger man Pensulo}

The study first looks at Pensulo (pseudo name) a young man aged 27 years. At the time of interview in March, 2021, Pensulo was cohabiting with an older woman aged 37years. He reported to have been cohabiting with her for 2 years. When asked how they had managed to stay together for that period, Pensulo explained, 'a day or two to months after we began cohabiting were grim times for us.' He and his older woman partner had to lie low to put up with neighbourhood gossip. 'Where ever I went, I could literally see and hear people speaking in low tones while pointing at me. There were stares and gazes to the left and to the right as if I was nasty. My mother and my father together with my sisters disowned me for not being level with society. They claimed that I was a reproach to the family. They stopped talking to me.' Pensulo almost quit but something held him back. 'I almost quit.

Seriously I almost quit but I had already seen and tasted the side of my partner and found that she was so good, so caring and very supportive of me. She counselled me to live my own life and not to please society. Pensulo found something special in the older woman. 'Her love for me is real, genuine, mature and deep. I cannot find such love elsewhere. When everyone deserted me including my own family, she was there for me.' Pensulo chained together his partner's goodness. 'She has made me to discover who really I am, the potential I have, oh! for me she is a wonderful woman who has assisted me to grow up, and to look at life with mature lenses. She respects me and treats me tenderly. I always tell her thank you babe each time she does something good.' He felt he could not let go of his partner for the sake of society. 'I feel it would be cruel to desert her for a younger woman who would nag me and make my life unbearable. It's not always that for one to find peace and happiness everything has to break right with society.' When Pensulo was asked whether he and his older woman partner experienced societal brutality he responded, 'the moment people learn that as a younger man you are having sexual relations with an older woman, society picks up stones, hurls them at both the older woman and the younger man but with the passage of time, society's fury lessens to a point where you get accepted and integrated.'

\section{Compatibility of behaviour}

Participants' responses indicated that compatibility of behaviour between the older woman and her younger man partner sometimes was the reason that held their relationship in place. Social activities such as drinking together assisted the couple to adhere together in spite of societal opposition. The following case study demonstrates this finding.

\section{Case study of- younger man Dausi}

The study moves to a narrative from one of the female participants whose young brother aged 23 years hooked up with an older woman aged 45 years. 'My brother, Dausi (pseudo name) became a huge nuisance to the family after he completed school. 'He joined a team of useless boys in the neighbourhood. Together they began to drink heavily and carelessly. Dad chased him away from home for being loud whenever he came home drunk.' Dausi went out and took refuge at an older woman's house. The woman brewed alcohol which Dausi could buy and drink before cohabitation. 'The woman received him and that's how they began to cohabit. Even after dad cooled down and recalled him to come back home he says he is comfortable staying with his older partner.' From the report, Dausi had clocked a year cohabiting with the older woman. When asked what had made the agedescripant couple stick together that long, the respondent said, 'they have a lot in common. My brother drinks. The older woman drinks too. They drink together, sing together and dance together. They are birds of the same feathers sticking together. Substance abuse equalizes them. Alcohol helps them to lump in and keep going.'

\section{Case study of- older woman- Tiyankhenji}

The case of an older woman by the name of Tiyankhenji (pseudo name) was narrated by a female participant. In her narrative, she reported that the older woman who was an active player in the older woman/younger man relationship was her neighbour. The woman in question was a widow with grown up children. She was about 40 years old. Across the street overlooking the widow's house lived a young man aged 19 years. The young man, though not trained in Electrical Engineering was very good following a sustained apprenticeship with his father. One day, he was requested by the widow to go and fix an electrical fault at her house. Even after the problem was fixed the young man kept on frequenting the widow's house to the chagrin and suscipicion of her grown up children. One day after the older woman and her younger man were tracked and caught ready-handed in a sexual act by her own children, they quizzed her why she was doing that with someone the age of her son, the widow told her children, 'please leave him alone don't chase him. I love him and we won't stop. The age-descripant couple was reported to have continued seeing each other despite societal opposition. They claim 'they love each other.' 
Socio-economic gain

Participants' indicated that majority of older woman/younger man relationships endured months and years because younger men felt empowered economically. Their socio-economic life changed for the better because their older women partners gave them money, bought them clothes, sponsored their education and opened socio-economic doors wide allowing them to access personal vehicles including bank accounts. The case study below provides this finding.

\section{Case study of -younger man Kangachepe}

The case of Kangachepe (pseudo name) younger man aged 26 years was narrated by a male participant- his close friend. Kangachepe completed school and had found a temporal job as a general worker at one of the local companies. Having worked for three years he was very conversant with the operations of the department he worked from. The day supervisors from the capital city- Lusaka visited the company in July 2019, the head of department and his vice were away forcing Kangachepe to stand in and provide an orientation. The supervisors were impressed with the way Kangachepe handled the tour. An older woman of about 44years even demanded his contact number. 'My friend shared with me that she demanded my contact phone number to which he gladly gave her.'

Two days later, the older woman called him and repeated that she was impressed with him. 'From calling it is reported that the older woman switched to Whatsapp. Kangachepe told me that through the back and forth Whatsapping, he learnt that the older woman was married and had left her family in another town after she had been transferred on promotion to Lusaka.' As the two continued to communicate, the older woman invited him to Lusaka. 'The older woman invited my friend Kanga to Lusaka. They shared a bed. This is how their intimancy started.' Their romantic relationship survived the entire 2020 and spilled over into 2021.

At the time of interview in the month of March, 2021, Kangachepe's friend reported that the two were still on. When asked whether he knew what precisely kept their relationship alive nearly two years, we were told that Kangachepe says, 'I don't think I can end the relationship with this older woman because she sends me money and air time anytime I ask her. I am never broke. I have the rare privilege of driving her car. She also promises to sponsor my college education. The woman is just special. She has changed my economic outlook. I was a nobody now I am a somebody.' Kangachepe is reported to admit, 'there are times when I feel whatever I am doing with her especially that she is a married woman is utterly bad. I sometimes promise myself not to call her on phone but later on I am compelled to call her because I feel I miss her very much. I should admit that I feel so emotionally attached to the older woman to the extent that I look at marrying somebody else a waste of time.'

\section{DISCUSSION}

Literature on cross-generational romantic relationships between older women and younger men is rapidly gaining popularity in both social science and the media. Madipoane Masenya (2017) rightly observed that there still exists 'considerable gap in knowledge surrounding such relationships' (Masenya 2017: 121). Existing literature has very little to share on who initiates older woman/ younger man intimate relationships, and how such partnerships develop and survive despite societal assault. The objective of this study was to explore on the initiators of romantic large age-gap relationships, how these relationships form up and what makes the players stick together for months to years despite living under daily scrutiny of society.

This study found that except one, all cougar/boy relationships were not planned by older women. Intimate relationships developed coincidentally without an older woman crafting a detailed seductive war plan to hunt and date a younger man. In all instances, younger men appeared on the scene innocent and entirely absorbed in the pursuit of their own activities. But older women positioned themselves, spoke and acted in a way that invited younger men to form a romantic relationship with them. The invitation was not premised on challenging social norms- women playing the role of passive players in the initiation of a dating game. Older women's words and actions entirely influenced the evolution of older woman/younger man romantic relationship. By suggesting sex as the alternative means at their disposal to service their debt meant opening the door wide to hormone-charged younger men. These findings tally with the study findings conducted in Canada by Alarie (2019). Milaine Alarie (2019)'s study titled, They're the Ones Chasing the Cougar': Relationship Formation in the Context of Age-Hypogamous Intimate Relationships found that the traditional script for sexuality was still strong among Canadian women but elements in older women's words and actions influenced younger men to form romantic relationships with them (Alarie, 2019:471).

This study also found that younger men were compelled into an older woman/younger man relationship in defense of their socio-cultural masculine identity in the face of threats to their masculine identity. Statements such as 'are you really man enough to pester a woman for her money when you can still get what you want through other means' was an affront to younger men. They could not take it lightly and brush it off. They felt their masculine identity was under threat therefore, they moved swiftly to win back their masculine identity. The findings are consistent with those of James Kim (2017). $\operatorname{Kim}(2017)$ observed that males responding to feedback indicating a lack of masculinity are likely to engage in behaviour associated with the aspect of their identity to the point that they will behave in ways that are extreme versions of their identity (Kim 2017:8).

On age-gap descripant relationships, this study found that agedescripant couples who appreciated each other stuck together longer despite cultural stereotypes. Younger men who 
recognized the loving care from their older female partners and verbalized their appreciation by saying 'thank you', 'I love you', or expressed their appreciation through small acts of kindness adhered to each other more strongly and were not willing to shade off each other's attachment and bow to societal prescription. Study by Jacqui Gabb, Martina KlettDavies, Janet Fink and Manuela Thomae (2013) found that 'simply saying thank you was highly prized' among couples and that a 'sense of feeling appreciated helped to bolster a relationship' (Gabb et al. 2013). This study also found that younger men endured cultural stereotypes and chose to strictly adhere to a mom-son intimate relationship for economic gain. They economically benefitted from older women. Aged women romantic partners gave them money, airtime, bought them clothes and shoes, sponsored their education, gave away their own cars to be driven around by their younger partners, and took them to luxurious places. These findings support those of Masenya (2017) in a study conducted in South Africa, where some older richer heterosexual women due to their economic achievements attracted younger men to form enduring intimate relationships.

On societal brutality, this study found that, with time, society's violent opposition exhibited at the onset of an older woman/younger man romantic relationships wanes down as long as the age-descripant couple sticks together. The beginning of older woman/ younger man relationships is faced with direct opposition. Offensive comments, social censure, provocative gestures, stares and gazes are all hurled against the couple immediately they choose to flout social norms. Depending on how the couple treated each other, with time, and as society changed, its aggression also began to wind down. The findings support insights by Rebecca Neumann (2011). In Neumann (2011)'s study entitled Predator, Prisoner, and Role Model: The Evolving Figure of Mrs Robinson it is noted that society's measure of a successful romantic relationship has been shifting from a traditional relationship that produced offspring, to a relationship where both partners were emotionally satisfied'(Neumann 2011:6) and this change in societal orientation to romantic relationships to some extent lessens society's virulence against age-descripant couples.

\section{CONCLUSION}

May-December romantic relationships are rapidly rising in today's changing societies. Scholarly interest and popular culture are increasingly recognizing this social phenomenon. However, evolution and survival of these relationships remain obscure in academic circles. The objective of this study was to find out how large age gap romantic heterosexual relationships develop and survive societal opposition. This study found that majority of these relationships developed coincidentally. Except in one case, the study found that older women did not follow a carefully laid plan to hook younger men. However, older women's words, actions and non verbal language influenced the course younger men took to initiate romantic relationships with them.

\section{AUTHORS' CONTRIBUTIONS}

JT was responsible for the study conception and design, data collection, and analysis. PM edited the manuscript.

\section{ACKNOWLEDGEMENTS}

The authors are grateful to the participants for their willingness to participate in the study.

\section{REFERENCES}

[1]. Ajrouch, K. J., Blandon, A.Y., Antonucci, T.C. (2005). In McWilliams, S., Barret, A.E.(2017). Online Dating in Middle and Later Life: Gendered Expectations and Experiences. Journal of Family Issues 2014, 35(3) 411-436 DOI: 10.1177/0192513X12468437

[2]. Alarie, M.(2019). 'They're the Ones Chasing the Cougar": Relationship Formation in the Context of Age-Hypogamous Intimate Relationships. Gender \& Society June, 2019 DOI: $10.1177 / 089124329839670$

[3]. Dworkin, S.L.(2012). Sample Size Policy for Qualitative Studies Using In-depth Interview DO:10.1007/S10508-012-0016-6 Arch Sex Beha(2012)41:1319-320

[4]. Fan, D.(2016). Older Women with Younger men- a new relationship of conspicuous consumption https://doi.org/10.2991/ssehr-16.2016.189

[5]. Gabb, J., Kett-Davies, Fink, J., Thomae, M.(2013). Enduring Love? Couple Relationships in the $21^{\text {st }}$ Century Survey Findings Report. The Open University

[6]. Kim, J.(2017). 'What did you Call me?' The effect of masculinity threat on men and likelihood of engaging in risk-taking behaviour. Master's Thesis University of Hawai'i Manoa

[7]. Kuzel, A.,1992, Sampling in qualitative inquiry. In: Crabtree, B. and Miller, W., Eds., Doing Qualitative Research. Newbury Park, Sage

[8]. Masenya, M. (2017). Reading Proverbs 7 in the context of female 'blessers and sugar mamas in South Africa Scriptura 116 (2) 120132 http://dx.doi.org/10.7833/116-2-1316

[9]. Neumann, R.(2011). Predator, Prisoner, and Role Model: The Evolving figure of Mrs Robinson Berkeley Undergraduate Journal https://escholarship.org/uc/item/186959sr24/17

[10]. Proulx, N., Caron, S.L., Logue, M.E. (2006). 'Older Women/Younger Men'. Journal of Couple \& Relationship Therapy, 5: 4, 43-64 DOI: 10.1300/J398V05N04_03HTTP://DX.DOI.org/10.1300/J398v05n 04_03

[11]. Redmond, M.V.(2015). Social Exchange Theory. English Technical Reports and White Papers S. http://lib.dr.iastate.edu/engl_reports/5

[12]. Spinelli, L. H. P., Hantori, W, T., Cordeiro de Sousa, M. B.(2010). Why do women not prefer much older men? A hypothesis based on alterations in male reproductive physiology related to increased age Estudos de Psicologia(Natal) 15(1:119-123 DOI: 10.1590/S1413-294X201000100016 https://www.researchgate.net

[13]. Sprecher, S.(2010). Social Exchange theories and Sexuality. The Journal of Sex Research vol $35 \quad$ (1) $32-40$ https://doi.org/10.1080/00224499809551915 